\title{
Effectiveness of catechin extract of green tea (camellia sinensis) on porphyromonas gingivalis
}

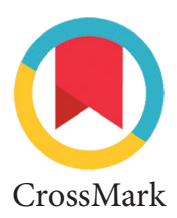

\author{
Fajriani, ${ }^{1 *}$ Sartini, ${ }^{2}$ Hendrastuty Handayani, ${ }^{1}$ Dekarini D. Putri ${ }^{3}$
}

Abstract

Objective: To find out the effectiveness of catechin extract of green tea (Camellia sinensis) on Porphyromonas gingivalis.

Material and Methods: The independent variables were catechin extracts of green tea (Camellia sinensis) starting from the 40\%, 20\%, $10 \%, 5 \%, 2.5 \%$ and $1.2 \%$ concentrations. The dependent variables were the Minumum Inhibitory Concentration (MIC) and the Inhibition zone of bacterial growth of Porphyromonas gingivalis. Control variables were time, culture medium, and temperature. The sample of research were Porphyromonas gingivalis which has been bred and catechin extract of green tea (Camellia sinensis) that extracted by maceration method..

Results: At the $40 \%, 20 \%, 10 \%$, and 5\% concentrations, the growth of Porphyromonas gingivalis did not change. As for the $2.5 \%$ and $1.25 \%$ concentrations, bacterial growth has occurred.

Conclusion: Catechin extract of green tea (Camellia sinensis) was effective in inhibition of Porphyromonas gingivalis.
${ }^{1}$ Department of Pediatric Dentistry, Faculty of Dentistry, Hasanuddin University, Makassar, Indonesia 2Department of Pharmaceutical Microbiology, Faculty of Pharmacy, Hasanuddin University, Makassar, Indonesia

${ }^{3}$ Faculty of Dentistry, Hasanuddin University, Makassar, Indonesia

*Correspondence to: Fajriani, Department of Pediatric Dentistry, Faculty of Dentistry, Hasanuddin University, Makassar, Indonesia fajiani@gmail.com

Received: 3 December 2020

Revised: 7 January 2021

Accepted: 1 March 2021

Available Online: 1 April 2021

Keywords: Camellia sinensis, Catechin extract, Porphyromonas gingivalis

Cite this Article: Fajriani, Sartini, Handayani H, Putri DD. 2021. Effectiveness of catechin extract of green tea (camellia sinensis) on porphyromonas gingivalis. Journal of Dentomaxillofacial Science 6(1): 27-30. D0I: 10.15562/jdmfs.v6i1.1120

\section{Introduction}

Green tea has received more special attention in the last two decades due to its favorable results for human health problems. Green tea was one of the herbal plants. Herbal plants had different types of active component compositions when planted in different places, geographical locations, forms of presentation and times. These affected the determination of antibacterial activity. ${ }^{1}$

This antibacterial activity is affected by the concentration of polyphenols in green tea extracts. The Minimum Inhibitory Concentration of polyphenols was $0.25-1 \mathrm{mg} / \mathrm{ml}$. Polyphenols of green tea were effective in inhibiting the growth of bacteria that caused periodontium diseases, namely Porphyromonas gingivalis and cariogenic bacteria such as streptococcus mutans and streptococcus sobrinus. The use of tea polyphenol mouth rinses with $0.05 \%$ or more concentration has also been proven to inhibit the formation of dental plaque. $^{2}$

The $0.5 \%$ concentration of green tea extract had a greater effect on increasing salivary volume. Green tea was also alkaline and bitter-tasted. The alkaline nature of green tea maintained the acidbase balance of body fluids. The bitter taste of green tea due to the presence of catechins. It stimulated salivary secretion. The total polyphenols in green tea were $10.81 \%$ of the dry weight of tea leaves, while the total polyphenols in solid extracts of green tea ranged from $37-56 \%$ of the dry weight. ${ }^{2}$

Green tea contained polyphenols with catechin compounds, the highest content of catechin in green tea was EGCG, around 50-80\%. EGCG actively suppressed the occurrence of inflammation, killed and inhibited various microorganisms, and had the ability as an antioxidant. The polyphenols content of 100 grams of green tea leaves obtained about 25\%. The EGCG contained in green tea had an antibiotic effect that worked directly by way of antibiotics that damaged cell membranes in bacteria, inhibited the existing synthesis of fatty acids, and inhibited the activity of enzymes present in bacteria. ${ }^{3}$

Polyphenols were antibacterial substances that are proven to be able to maintain the body's immune system by phagocytosis of bacteria or other foreign substances that entered the body. This polyphenol content is used to kill the bacteria porphyromonas gingivalis which caused periodontitis. $^{4}$

Based on the background described above, we aimed to find out the effectiveness of catechin extract of green tea (camellia sinensis) on porphyromonas gingivalis.

\section{Material and Methods}

The type of research used in this study was an experimental laboratory research. The research used 
was a posttest only control group design using the dilution method and disk-diffusion method. The study was conducteded in June 2020 at the Microbiology Laboratory, Faculty of Medicine, Hasanuddin University, and PT IFI South Sulawesi.

There were three variables in this study. The independent variables were catechin extracts of green tea (camellia sinensis) starting from the $40 \%$, $20 \%, 10 \%, 5 \%, 2.5 \%$ and $1.2 \%$ concentrations. The dependent variables were the Minumum Inhibitory Concentration (MIC) and the Inhibition zone of bacterial growth of porphyromonas gingivalis. Control variables were time, culture medium, and temperature. The sample of research were Porphyromonas gingivalis which has been bred and catechin extract of green tea (camellia sinensis) that extracted by maceration method.

The tools were analytical scales, test tubes, test tube racks, glass jars, petri dishes, micropipettes, paper disks, caliper, measuring cups, incubator, autoclaves, tweezers, bunsen, filter paper, Erlenmeyer flasks, $1 \mathrm{~mL}$ spoit, paper label, funnel, handscoon and mask, scrub (mac carymey) bottle, water bath and vortex. The materials were Porphyromonas gingivalis isolates, catechin extract of green tea (Camellia sinensis), amoxicillin, Muller Hinton Agar (MHA) medium, DMSO (Dimethyl sulfoxide), spritus, Mc farland 0.5 (diluted), aluminum foil, and sterile aquades.

Petri dishes are wrapped in aluminum foil. Erlenmeyer flask is filled with $250 \mathrm{ml}$ of aquades and then covered with compacted cotton. All tools are sterilized in an autoclave at $121^{\circ} \mathrm{C}$ for 2 hours.

Fresh green tea (camellia sinensis) leaves are washed and dried in a drying cupboard at $45^{\circ} \mathrm{C}$ for 48 hours. After drying, pollinated using a pollinating machine with a hole diameter of $1 \mathrm{~mm}$ until finished and weighed with a balance sheet so that the dry weight is obtained. Then the extraction process is carried out using a water solvent with a high-pressured extraction technique. The pollen is put into a jar containing $70 \%$ ethanol while stirring for 30 minutes and allowed to stand for at least 1-2 hours.

Table 1 Results of the measurement of the inhibition zone diameter $(\mathrm{mm})$ on porphyromonas gingivalis

\begin{tabular}{lccccc}
\hline $\begin{array}{c}\text { Type of } \\
\text { intervention }\end{array}$ & $\begin{array}{c}\text { Concentration } \\
\text { (\%) }\end{array}$ & I & II & III & Mean \\
\hline Catechin extract of & 5 & 6.9 & 8 & 8.1 & 7.67 \\
green tea & 20 & 9.2 & 9 & 10.3 & 9.50 \\
& 40 & 13.3 & 12.4 & 12.6 & 12.77 \\
Control (+) Amoxicillin & & 25.4 & 16 & 17 & 16.17 \\
Control (-) DMSO & & 6.3 & 6.3 & 27.9 & 26.67 \\
\hline
\end{tabular}

\section{Results}

The result is filtered 3 times with a Buchner funnel to obtain filtrate and residue. The filtrate obtained was evaporated using a vacuum rotary at $70^{\circ} \mathrm{C}$ and heated with a water bath so that a thick extract was obtained. This thick extract is poured into a porcelain cup and heated again with a water bath while continuing to stir. The end result is a green tea extract with a concentration of $100 \%$. Pure green tea extract was diluted using in sterile aquades in accordance with predetermined concentrations, namely $40 \%, 20 \%, 10 \%, 5 \%, 2.5 \%$ and $1.5 \%$.

The dilution of green tea extract was the $40 \%$, $20 \%, 10 \%, 5 \%, 2.5 \%$ and $1.5 \%$ concentrations. Each bottle was given $1 \mathrm{ml}$ of green tea stock solution pipetted into a sterile petri dish. Then six bottles are added $9 \mathrm{ml}$ of sterile MHA (Muller Hilton Agar) which is still melting. After it cools, each petri dish is scraped with bacterial suspensions equivalent to 105 (108 Mc Farland 0.5 bacterial stock) diluted to 105 . All Petri dishes were incubated at $37 \mathrm{oC}$ for 24 hours in anaerobic conditions. The Minimal Inhibitory Concentration is calculated as the smallest concentration that did not show bacterial growth. After table 1 Results of the measurement of the inhibition zone diameter $(\mathrm{mm})$ on Porphyromonas Gingivalis.

From table 1, descriptively is seen that the $10 \%$ concentration of catechin extract of green tea has the smallest mean of the inhibition zone $(9.5 \mathrm{~mm})$ when compared to the entire concentrations of catechin extract of green tea. The $40 \%$ concentration of catechin extract of green tea has the biggest mean of the inhibition zone $(16.17 \mathrm{~mm})$. lin buffer solution and taken to the Anatomic Pathology Laboratory of the Faculty of Medicine, Universitas Gadjah Mada to be processed up to the immunohistochemical staining (MMP-9polyclonal antibody) and PAS staining. With the Optilab camera, microscopic images were taken on the results of the preparation. MMP-9expression data and epithelial thickness were calculated with Image-J software combined with direct observation by anatomical pathologists figure $1 \mathrm{~A}$ and figure $1 \mathrm{~B}$.

After the data normality test with the ShapiroWilk test is performed, the DMSO (negative control) group showed a p-value $<0.05$ so that the data were not normally distributed. After the data transformation is performed, a p-value $<0.05$ is still obtained in the DMSO (negative control) group, which means the group is not normally distributed. Therefore, further hypothesis test cannot be performed with the OneWay ANOVA and Post Hoc LSD (Least Significant Difference) parametric tests, but instead using 
Table 2 Results of statiscal test of the inhibition zone on porphyromonas gingivalis

\begin{tabular}{lccc}
\hline $\begin{array}{c}\text { Type of } \\
\text { intervention }\end{array}$ & $\begin{array}{c}\text { Concentration } \\
\text { (\%) }\end{array}$ & $\mathbf{N}$ & Normality Test* \\
\hline $\begin{array}{l}\text { Catechin extract of } \\
\text { green tea }\end{array}$ & 40 & 3 & 0.637 \\
& 20 & 3 & 0.407 \\
& 10 & 3 & 0.274 \\
Control (+) Amoxicillin & 5 & 3 & 0.144 \\
Control (-) DMSO & & 3 & 0.956 \\
\end{tabular}

*Shapiro Wilk test: $\mathrm{p}>0.05$; normally distributed data.

\section{Table 3 Results of Kruskal-Wallis Test}

\begin{tabular}{llll}
\hline $\begin{array}{l}\text { The null } \\
\text { hypothesis }\end{array}$ & Test & p value & Conclusion \\
\hline $\begin{array}{l}\text { Catechin extract of } \\
\text { green tea cannot } \\
\text { inhibit the growth of } \\
\text { porphyromonas } \\
\text { gingivalis }\end{array}$ & $\begin{array}{l}\text { Kruskal } \\
\text { Wallis }\end{array}$ & 0.005 & $\begin{array}{l}\text { The null hypothesis } \\
\text { was rejected }\end{array}$ \\
& & & \\
\end{tabular}

${ }^{*}$ Kruskal-Wallis test: $\mathrm{p}>0.05$; the null hypothesis is accepted

Table 4 Results of Post Hoc Mann-Whitney statistical test of the inhibition zone on Porphyromonas gingivalis (the $\mathbf{4 0} \%$ concentration)

\begin{tabular}{lcc}
\hline Treatment group & Comparison & p-value \\
\hline Concentration $40 \%$ & $20 \%$ & 0.05 \\
& $10 \%$ & 0.05 \\
$5 \%$ & 0.05 \\
$\mathrm{~K}(+)$ & 0.05 \\
$\mathrm{~K}(-)$ & 0.46 \\
\hline
\end{tabular}

Table 5 Results of Post Hoc Mann-Whitney statistical test of the inhibition zone on Porphyromonas gingivalis (the $20 \%$ concentration)

\begin{tabular}{lcc}
\hline Treatment group & Comparison & p-value \\
\hline Concentration 20\% & $40 \%$ & 0.05 \\
& $10 \%$ & 0.05 \\
& $5 \%$ & 0.05 \\
& $\mathrm{~K}(+)$ & 0.05 \\
$\mathrm{~K}(-)$ & 0.46 \\
\hline
\end{tabular}

alternative tests, namely the Kruskal-Wallis and Post Hoc Mann-Whitney non-parametric test table 2.

Table 3 in the Kruskal-Wallis statistical test, $\mathrm{p}=0.005(\mathrm{p}<0.05)$ is obtained, which means the alternative hypothesis is accepted. So, it can be concluded that the catechin extract can inhibit the growth of porphyromonas gingivalis as indicated by the presence of the inhibition zone diameter in different treatment groups according to the concentration of the catechin extract. To find out which group concentrations had differences, a Post Hoc analysis must be performed. The Post Hoc analysis used for the Kruskal-Wallis test was the Mann-Whitney test.

In the Mann-Whitney test, $\mathrm{p} \leq 0.05$ is obtained for comparison between concentrations and comparison between concentrations of catechin extract of green tea with Amoxicillin (positive control) and DMSO (negative control), so alternative hypotheses are accepted which means there were significant differences between groups. The results of Post Hoc MannWhitney Test can be seen in the following table 4 .

Table 4 at the $40 \%$ concentration of catechin extract of green tea when compared with the $20 \%$, $10 \%, 50 \%$ concentration, positive and negative controls had $\mathrm{p} \leq 0.05$ which means there was a significant difference or had a different effect.

Table 5 at the $20 \%$ concentration of catechin extract of green tea when compared with the $40 \%$, $10 \%, 5 \%$ concentration, positive and negative controls had $\mathrm{p} \leq 0.05$ which means there was a significant difference or had a different effect.

\section{Discussion}

In the inhibition zone test using catechin extract of green tea (camellia sinensis) on the growth of porphyromonas gingivalis, it was seen that the inhibition zone formed is increased in proportion to the increasing concentration of the extract. Camellia Sinensis had many useful phytochemical compounds. This was due to green tea (camellia sinensis) leaves contained tannins, flavonoids, polyphenols, and methylxantyl compounds. ${ }^{5}$

Phenol compounds are generally known as disinfectants used to kill pathogenic microorganisms. Flavonoids were the largest phenol compounds in nature and have been known to have biological activities as antioxidants, antimelanogenesis and antimutagenesis. Polyphenol compounds have been shown to have antibacterial activity. In addition, the leaves also contained essential oils and also coumarin. ${ }^{6-8}$ Camellia sinensis, is known to have a good antibacterial effect. Suggested that each $100 \mathrm{gr}$ of tea leaves contained $17 \mathrm{~kJ}$ calories, $75-80 \%$ water, $25 \%$ polyphenols, $20 \%$ protein, $4 \%$ carbohydrates, $2.5-4.5 \%$ caffeine, $27 \%$ fiber, and $6 \%$ pectin. The other contains were solids and consisted of organic and inorganic. The most important organics in its process included polyphenols, carbohydrates, and their product, nitrogen bonds, pigments, enzymes, 
and vitamins. Polyphenols or catechins in green tea were antibacterial substances that have been proven to be able to maintain the body's defenses by phagocytosis of bacteria or foreign substances that enter the body. ${ }^{9-12}$ The green tea has been widely studied in the field of dentistry as an antibacterial.

This study proved that extract of green tea (camellia sinensis) had a bacterial inhibition on porphyromonas gingivalis with the $10 \%$ concentration had the smallest mean of inhibition zone $(9.5 \mathrm{~mm})$ when compared to the entire concentrations of extract of green tea (camellia sinensis). The zone of inhibition at the $40 \%$ concentration had the biggest inhibition zone $(16.17 \mathrm{~mm}) .^{13-15}$

At the $40 \%$ concentration of catechin extract of green tea when compared with the $20 \%, 10 \%$, $5 \%$ concentrations, positive and negative controls had $\mathrm{p} \leq 0.05$ which means there was a significant difference or had a different effect. ${ }^{16}$

Thus, the bacterial activity only can be observed in diffusion methods to see inhibition zones of the extract of green tea (camellia sinensis). The $40 \%$ concentration had the biggest inhibition zone $(16.17 \mathrm{~mm})$ and the inhibition zone was greater than the positive control (amoxicillin) which is used as a comparative antibiotic of green tea (camellia sinensis) extract. This study has proven that green tea (camellia sinensis) extract was effective in the inhibition of Porphyromonas gingivalis. Thus, the hypothesis was accepted. ${ }^{17}$

\section{Conclusion}

Catechin extract of green tea (camellia sinensis) was effective in inhibition of porphyromonas gingivalis. The $5 \%$ concentration of green tea (camellia sinensis) extract had smallest mean of the inhibition zone $(7.67 \mathrm{~mm})$ when compared to the entire concentrations of green tea (camellia sinensis) extract. The $40 \%$ concentration of green tea (camellia sinensis) extract had greatest inhibition zone $(16.17 \mathrm{~mm})$. Minimal Inhibitory Concentration (MIC) of each green tea extract from $1.5 \%-2.5 \%$ concentrations continued to occur bacterial growth and the 5\%,10\%, 20\%, and $40 \%$ concentrations did not occur bacterial growth.

\section{Acknowledgment}

Thank you for the Faculty of Dentistry, Hasanuddin University to support this research.

\section{Conflict of Interest}

The authors report no conflict of interest.

\section{References}

1. Alibasyah ZM, Ningsih DS, Ananda SF. In vitro inhibition of probiotic drink of cow's milk yogurt against porphyromonas gingivalis. J Syiah Kuala Dent Soc 2018;2: 65-75. (In Indonesia)

2. Arjuna A, Pratama WS, Sartini, et al. An initial study on anti-biofilm activity of green tea dan black tea extracts on Streptococcus mutans via mictotiter plate assay. Galenika J Pharm 2018;4: 44-49.

3. Berkowitz RJ. Causes treatment and prevention of early child caries: A microbiologic perspective. J Can Dent Assoc 2003;69: 304-307.

4. Sofyani CM, Chaerunnisa AY, Rusdiana T. Review: Validation of high-performance liquid chromatography analytical methods for determination of comparable dissolution test levels for amoxicillin tablets. Farm 2018;16: 324-330. (In Indonesia)

5. Dwipriastuti D, Putranto RR, Anggarani W. The difference in the effectiveness of chlorhexidine gluconate $0.2 \%$ with green tea (camellia sinensis) on the amount of porphyromonas gingivalis. ODONTO Dent J 2017;4: 50-54. (In Indonesia)

6. Grenierl GV, Mayrand D. The capacity of porphyromonas gingivalis to multiply under ironlimiting conditions correlates with its pathogenicity in an animal model. J Dent Res 2001;80: 1678-1682.

7. Habiburrohman D, Sukohar A. Antioxidant and antimicrobial activity on green tea polyphenols. J Agromedicine Unila 2018;5: 587-591. (In Indonesia)

8. Anjarsari IRD. Indonesian tea catechins: Prospects and benefits. Jurnal Kultivasi 2016;15: 99-106. (In Indonesia)

9. Jeffrey. Prevention and Treatment of Early Childhood Caries (ECC). J Med Health 2016;1: 296-304. (In Indonesia)

10. Kawashita Y, Kitamura M, Saito T. Early childhood caries. Int J Dent 2011;2011: 725320.

11. Paramita DN, Wahyudi MT. Antibacteri effect of green tea (camellia sinensis) to staphyloccos aureus in vitro. J Medika Planta 2011;1: 67-74. (In Indonesia)

12. Nedyani V, Hayati M, Bakar A. Effects of gargling green tea extract (camellia sinensis) and salivary viscosity in gingivitis sufferers. Insisiva Dent J,2019;8: 1-8. (In Indonesia)

13. Richard JL, Howard FJ. Life below the gum line: Pathogenic mechanisms of porphyromonas gingivalis. Microbiol Molec Biol Rev 1998;62: 1244-1263.

14. Sutjipto WR, Herawati, Kuntari S. The prevalences of early childhood caries and severe early childhood caries in preschool children at Gunung Anyar Surabaya. Dent J 2014;47: 186-189. (In Indonesia)

15. Takahashi, Schachtele CF. Effect of $\mathrm{pH}$ on the growth and proteolytic activity of porphyromonas gingivalis and bacteroides intermedius. J Dent Res 1990;69: 1266-1269.

16. Zeniusa P, Ramadhian MR. The effectiveness of green tea ethanol extract in inhibiting the growth of escherichia coli. J Majority 2017;7: 26-30.

17. Trilaksana AC, Saraswati A. Efficacy of green tea leaf extract (camellia sinensis) with $\mathrm{NaOCl} 2.5 \%$ againts enterococcus faecalis as an alternative solution for root canal irrigation. J Dentomaxillofac Sci 2016;1: 58-62.

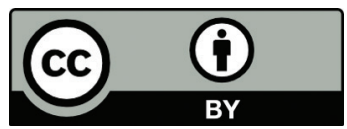

This work is licensed under a Creative Commons Attribution 